TITLE:

\title{
ECHINOIDS FROM HOKKAIDO AND THE NEIGHBOURING SUBARCTIC WATERS
}

\author{
$\operatorname{AUTHOR}(S)$ :
}

Utinomi, Huzio

\section{CITATION:}

Utinomi, Huzio. ECHINOIDS FROM HOKKAIDO AND THE NEIGHBOURING SUBARCTIC

WATERS. PUBLICATIONS OF THE SETO MARINE BIOLOGICAL LABORATORY 1960, 8(2): 337 350

\section{ISSUE DATE:}

1960-12-20

URL:

http://hdl.handle.net/2433/174645

RIGHT: 


\title{
ECHINOIDS FROM HOKKAIDO AND THE NEIGHBOURING SUBARCTIC WATERS ${ }^{1,2)}$
}

\author{
Huzio UTINOMI \\ Seto Marine Biological Laboratory, Sirahama
}

With Plates XXXVII-XL

Our knowledge of the echinoid fauna of the northern territories of Japan is restricted to the descriptive works by early scientists and the local faunal notes by recent workers. No extensive systematic work treats them in detail, and the preparation of such an account must await more extensive collections from the entire region and any ecological or faunal surveys in various localities around the coasts. Notable among these are Agassiz and Clark (1907), Yoshiwara (1898-1908), Clark (1912-1917), Mortensen (1927, 1929, 1928-1951), Ohshima (1933), IKEDA (1940) and Kawamura (1960).

This report on echinoids is based mostly upon specimens in the collection of the Hokkaido Fisheries Experimental Station and partly upon those in the collection of the Shirikishinai Marine Station of Hokkaido Gakugei University as well as in the collection of our Laboratory.

Most of the species herein recorded are all known species, which are finely illustrated and described in detail in MORTEnSEn's 'Monograph of the Echinoidea' (1928-51). However, some photographs of the representatives are given here mainly for local use, in order to make them easily recognizable.

Only of much interest from the zoogeographical view-point is the occurrence of a typical tropical form Phyllacanthus dubius (BRANDT), which is hitherto known only from the Bonin Islands, in the depth of about $20 \mathrm{~m}$, off Matuura, in the Tugaru Strait, where water is less warm though washed by the Tusima Current.

\section{Acknowledgments}

To the following in particular I am indebted for the loan or gift of specimens : Mr. Kazuhiro Kawamura of the Hokkaido Fisheries Experimental Station at Yoiti and Mr. Tatsuo YUSA of the Hakodate Branch of the same station, and also

1) Contributions from the Seto Marine Biological Laboratory, No. 356.

2) Contribution No. 6 from the Shirikishinai Marine Station for Biological Instruction, Hokkaido Gakugei University.

Publ. Seto Mar. Biol. Lab., VIII (2), 1960. (Article 26) 
Mr. Minoru Imajima of the Marine Station for Biological Instruction of the Hokkaido Gakugei University at Sirikisinai. Photographs were made through the courtesy of Dr. Isamu YAMAZI of our Laboratory.

\section{Systematics}

REGULARIA

\section{Order CIDAROIDEA}

Family Cidaridae GRAY

\section{Phyllacanthus dubius (BRANDT)}

(PI. XXXVII, figs. 1 and 2)

Cidarites (Phyllacanthus) dubia BRANDT, 1835, Prod. deser. anim. ab H. Mertensio..... p. 68. (not seen)

Phyllacanthus dubia A. AgAssiz, 1872-73, p. 150, 389. (not seen)

Cidaris (Leiocidaris) dubia YostrwARA, 1898, p. 147 ; pl. II (1906), figs. 2-5.

Phyllacanthus dubius Mortensen, 1928, Monogr. of Echinoidea, vol. I, p. 510, pl. 55, fig. 1 ; pl. 56 , figs. $1-2$; pl. 63 , figs. $4-6$; pl. 74 , fig. 7 ; pl. 78 , figs. $13-17$.

Japanese Name: Bakudan-uni (nom. nov.).

Material examined: One large specimen. Hukusima, Tugaru Strait, about $20 \mathrm{~m}$. T. Takahasi leg. VI-1959. In the collection of the Shirikishinai Marine Station.

Description: The test is flattened above and scarcely so below, where it passes gradually into the raised peristome. Sides beautifully arched and circumference rounded. It is about $75 \mathrm{~mm}$ in horizontal diameter, about $65 \mathrm{~mm}$ in vertical diameter, and the peristome is about $26 \mathrm{~mm}$ in diameter. There are usually 7 primary spines along the interambulacral zone. They are rather slender, cylindrical, slightly thicker in the basal part and about as long as the horizontal diameter of the test; the longest one is about $50 \mathrm{~mm}$ in length and about $4 \mathrm{~mm}$ in diameter just above the collar. The surface of the shaft is longitudinally ridged. Oral primaries are simple, slender, somewhat flattened but not club-shaped; they are all shorter than those on the sides, less than $18 \mathrm{~mm}$ long. Of the secondary spines, the scrobicular ones, attaining about $9 \mathrm{~mm}$ long, are most developed, flat. Smaller miliary spines scale-like, appressed, though slightly larger towards the anal opening.

Many bryozoans and Spirorbis-worms are attached to the primary spines.

Color: The test, as covered with its small spines, is dark purplish brown. The primary spines are brown, often with a few whitish bands near the tip. The oral primaries sometimes with a pinkish hue. The scrobicular spines and marginal ambulacral spines are lighter, yellowish.

Remarks: The genus Phyllacanthus is represented by seven species which are hitherto known only from tropical waters. 
This magnificent sea-urchin unexpectedly found in cold waters of Hokkaido is apparently referable to $P$. dubius (BRANDT) hitherto only known from the Bonin Islands on account of the slender primary spines as long as the horizontal diameter of the test, as distinguishable from the allied species P. imperialis (LAMARCK) (with relatively short thick primaries) recorded all over the Indo-Pacific and $P$. forcipulatus MORTENSEN (with longer, more slender primaries) recorded only from the Indian Ocean.

\section{Order LEPIDOCENTROIDA}

Family Phymosomatidae (POMEL) MEIssner

2. Glyptocidaris crenularis A. AGAssIz

(Pl. XXXVIII, figs. 3-4)

Glyptocidaris crenularis A. AgAssiz, 1863, p. 536. (not seen)

Phymosoma crenulare A. AgAssiz, 1872-74, Revision of the Echini, p. 487, pl. VII. a, figs. 6, 8, 9. Comptosoma crenulare YoshIWARA, 1898, p. 331; pl. VII (1906), figs. 1-6.

Glyptocidaris crenularis DöDERLEIN, 1906, p. 520 ; H. L. CLARK, 1912, p. 228, pl. 90, figs. 1-11; pl. 106, figs. 1-2 ; Diakonov, 1923, p. 231 ; Mortensen, 1929, Monogr. of Echinoidea, vol. II, p. 473, pl. XIX, fig. 1 ; NisIYAMA, 1937, p. 51 ; ChANG \& WoO, 1954, p. 128, pl. I, fig. 1 ; pl. II, fig. 1 .

Japanese Name: Tugaru-uni (nom. nov.).

Material examined: Two specimens. Sirikisinai, $25 \mathrm{~m}$. M. Imajima coll. 10 VIII-1957. Sirikisinai, $22 \mathrm{~m}$. M. ImajIma coll. 10-IX-1959. All in the collection of the Sirikisinai Marine Station.

Description: Two specimens here examined are rather large for the species as measured in $\mathrm{mm}$ in the following.

$\begin{array}{ccccc} & \text { h.d. } & \text { v.d. } & \text { Peristome (d.) } & \text { Longest spine (l.) } \\ \text { A } & 44 & 23 & 23 & 27 \\ \text { B } & 67 & 33 & 24 & 31\end{array}$

Test very low, hemispherical, yellowish in alcohol; when nuded, olive green. Aboral side of test greatly arched, oral side slightly sunken towards peristome.

Primary spines smooth, long, slender, sharply pointed at tip; light greyish brown, darker in the basal part. On the aboral side there is a clearly naked median space in the ambulacral zone. Tube feet spicules are characteristic, being elongate rods with a few holes in the middle. Globuliferous pedicellariae also characteristic, often in bearing a number of strong thorns bilaterally arranged on their stalk.

Occurrence: Known only from Northern Japan, from Hakodate to Inubô-zaki on the Pacific side (Nisiyama) and Japan Sea (Diakonov) to Dairen, N. China (Chang \& Woo). 10-158 $\mathrm{m}$ in depth. 


\section{Order CAMARODONTA \\ Family Strongylocentrotidae GREGORY \\ 3. Strongylocentrotus drøbachiensis (O. F. MULLER)}

(Pl. XXXVIII, figs. 5-6)

Echinus drфbachiensis O. F. MüLlER, 1776, Prodromus Zool. Danicae, p. 235. (not seen) Strongylocentrotus drdbachiensis A. AGAssIZ, 1872, Revision of the Echini, p. 162, 277. (not seen) H. L. Clark, 1912, p. 358.

- Mortensen, 1943, Monogr. of Echinoidea, vol. III $_{3}$, p. 198, pl. XXXIII, figs. 1-11; pl. LIX, figs. $1-5,10$.

BARANOBA, 1955, in Uschakov's Atlas of Invertebrates of the Far East seas of the USSR, p. 214, pl. LXIII, fig. 2.

Non: St. drфbachiensis YoshiwARA, 1900, Zool. Mag., vol. 12, p. 382 ; Zool. Mag., vol. 18 (1906), pl. XI, figs. 8-11 (=St. intermedius).

Japanese Name: Hokuyô-bahun-uni (nom. nov.).

Material examined: Two complete and two damaged specimens. $50^{\circ} 45^{\prime} \mathrm{N}$, $157^{\circ} 75^{\prime} \mathrm{E}$ (SE of Kamtchatka Peninsula), $220 \mathrm{~m}$. Bottom: sandy mud. Kudo coll. $5-\mathrm{X}-1959$.

The remainder in the collection of the Hokkaido Fisheries Experimental Station.

Description: Two complete specimens measure (in $\mathrm{mm}$ ) as follows:

$\begin{array}{cccc}\text { h.d. } & \text { v.d. } & \text { Peristome (d.) } & \text { Longest spine (1.) } \\ 63 & 29 & 23 & 15 \\ 66 & 29 & 24 & 13\end{array}$

Test low hemispherical, rather fragile in texture, dull white. Usually porepairs 5 to each arc. Primary spines slender, longer than $10 \mathrm{~mm}$, sharply pointed at tip, delicately ridged on surface. Secondary spines uniformly light greenish, tinged with brownish tint basally.

Occurrence: This circumpolar species occurs all over the arctic seas. In the Pacific region it appears to be common all over the Bering Sea and Aleutian Islands. Its occurrence from further south than Kamchatka is for the present unreliable. Indeed, St. drøbachiensis recorded and figured by Yoshiwara (1900, '06) from Urup Island of the Kuriles (and other arctic seas) is undoubtedly an error for St. intermedius. He recorded St. intermedius too from Japan in the text but did not illustrate it in the plate.

\section{Strongylocentrotus echinoides A. AgASSIZ et H. L. CLARK}

(Pl. XXXVIII, figs. 7-8)

Strongylocentrotus echinoides A. AGAssiz \& H. L. CLARK, 1907, p. 122; H. L. ClaRK, 1912, p. 360 , pl. 94 , figs. $13-16$, pl. 113, fig. 1. 
Strongylocentrotus echinoides IKEDA, 1940, p. 3, pl. II, fig. 3.

- Mortensen, 1943, Monogr. of Echinoidea, vol. $\mathrm{III}_{3}$, p. 219, pl. XXIV, figs. 7-12; pl. LX, figs. 1, 4-7, 14-15.

Japanese Name: Akatoge-bahun-uni (nom. nov.).

Material examined: Two specimens. 2 miles off Tokoro (near Abasiri) on the Ohotsk Sea side, $45 \mathrm{~m}$ (dredged). Bottom: mud and shell. K. Arima coll. VIII-1959.

The remainder in the collection of the Hokkaido Fisheries Experimental Station.

Description: The measurements of two specimens (in $\mathrm{mm}$ ) are as follows.

$\begin{array}{cccc}\text { h.d. } & \text { v.d. } & \text { Peristome (d.) } & \text { Longest spine (1.) } \\ 48 & 25 & 18 & 9 \\ 48 & 26 & 18 & 8\end{array}$

Both specimens apparently remind of the warm-water forms, such as Tripneustes or Pseudocentrotus in general appearance and coloration.

Test low hemispherical, oral side slightly sunken towards peristome. Porepairs usually 7 to each arc. Spines about 4-9 mm long, uniformly short, sharply pointed; slightly banded with orange or brickred color. Denuded test purple drab in color.

Occurrence: Shumushir Island (Agassiz et Clark), Paramushir Island (IKEDA), all lying in the North Kurile Islands. According to Mortensen, its distributional centre is in the Bering Sea. Not found from other coasts than the Ohotsk Sea side.

\section{Strongylocentrotus intermedius (A. AGASSIZ)}

(Pl. XXXIX, figs. 9-12)

Psammechinus intermedius A. AgAssiz, 1863, p. 357.

Strongylocentrotus intermedius A. AGASSIZ, 1872-74, Rev. of Echini, p. 164, 445. (not seen)

- H. L. ClaRK, 1925, p. 353 ; Mortensen, 1927, p. 476, pl. XIX, fig. 4; IKEDA, p. 1; Mortensen, 1943, Monogr. of Echinoidea, vol. $\mathrm{III}_{3}$, p. 225, pl. XXIV, figs. 1-6, 13-14 ; pl. XXV, figs. $12-14$; pl. LX, figs. $2,3,8-10,19$.

Japanese Name: Ezo-bahun-uni.

Material examined:

3 specimens. Saroma Lake, $5 \mathrm{~m}$. K. Kawamura coll. 16-IX-1959.

3 specimens. Abasiri, rocky shore, $3 \mathrm{~m}$. K. Kawamura coll. 19-III-1960.

2 specimens. Yoiti, rocky shore, $5 \mathrm{~m}$. K. Kawamura coll. 25-V-1960.

1 specimens. Yoiti, $4 \mathrm{~m}$. K. Kawamura coll. 29-X-1959.

2 specimens. Osyoro, rocky shore, $1 \mathrm{~m}$. K. Kawamura coll. 17-V-1960.

1 specimen. Off Kamiiso, Hakodate Bay. T. YUSA coll. VI-1957. 
2 specimens. Sirikisinai, rocky shore. M. ImajIMA coll. 22-V-1960.

1 albino specimen. Sirikisinai, $12 \mathrm{~m}$. M. ImajIma coll. 7-III-1958.

Description: This species, so often described and figured, is so well known that any further description would be superfluous. But it is interesting to record the occurrence of its albinism among the material from Sirikisinai.

In normal forms, the test is very low, regularly hemispherical, or somewhat rounded pentagonal in outline, flat above and below, slightly sunken towards the peristome. The spines are uniformly short, but their color varies considerably, being light or deep olive green, darker distalwards and terminating with white or reddish white tip. Tube feet are usually purplish or dark brown with white end. Denuded test purple drab or dark slate purple.

Measurements of some specimens from different localities (in $\mathrm{mm}$ ) are given below.

$\begin{array}{lcccc}\text { h.d. } & \text { v.d. } & \text { Peristome (d.) } & \text { Longest spine (1.) } & \text { Locality } \\ 61 & 31 & 19 & 6 & \text { Yoiti } \\ 65 & 36 & 19 & 7 & " \\ 51 & 30 & 15 & 5 & \text { Osyoro } \\ 57 & 30 & 16 & 6 & " \\ 50 & 28 & 15 & 5 & \text { Sirikisinai } \\ 51 & 28 & 13 & 6 & " \\ 57 & 27 & - & 8 & \text { Saroma-ko } \\ 58 & 28 & - & 8 & " \\ 60 & 31 & - & 8 & " \\ 44 & 24 & - & 5 & \text { Abasiri } \\ 53 & 26 & - & 5 & \text { Hakodate } \\ 35 & 19 & 13 & 5 & \end{array}$

An unusual albino specimen obtained at Sirikisinai is relatively large, $69 \mathrm{~mm}$ in horizontal diameter and $41 \mathrm{~mm}$ in vertical diameter. The test is not so flat as in the normal form, but slightly arched above and flat below. The circumference is rounded pentagonal. Spines are all short, slender and blunt-tipped. The test and spines are perfectly white. More interesting is the fact that the tube feet entirely lack the bihamate spicules peculiar to the species, as figured by MORTENSEN (1929, tetx-fig. 6).

Such an example of albinism in the echinoids has been recorded for Temnopleurus toreumaticus (LESKe) from Chan Ch'iao, North China (Chang \& Chao, 1951, p. 46).

Occurrence: Very common in northern parts of Japan, mainly all along Hokkaido and Sachalin. According to IKeda (1940), the southern limit of range in distribution is Onagawa, Miyagi-ken on the Pacific coast and Syônai, Yamagataken on the Japan Sea side. Littoral to ca. $35 \mathrm{~m}$ in depth. 


\section{Strongylocentrotus nudus (A. AGASSIz)}

(P1. XXXIX, figs. 13-14)

Toxocidaris nuda A. Agassiz, 1863, Synopsis of Echinoid., p. 356. (not seen)

Strongylocentrotus nudus A. AGASSIz, 1872-74, Rev. of Echin., p. 165, 448, pl. XXIV, figs. 2630. (not seen)

Yoshiwara, 1900 , p. 382 ; pl. XII (1906), figs. $1-2$.

Strongylocentrotus hokkaidensis DöDERLEIN, 1906, p. 518 (Hakodate, Sagami Bay).

Strongylocentrotus nudus H. L. CLARK, 1912, p. 363, pl. 94, figs. 17-23 (off Cape Tonin, Saghalin; Hakodate; Tugaru Strait).

- Mortensen, 1929, p. 474, pl. XIX, fig. 2 (Mutu Bay).

- Nisiy AMA, 1937, p. 54 (off Itinomiya, Tiba-ken).

- Diakonov, 1938, p. 496 (Siaukhu Bay, Japan Sea). (not seen)

- Mortensen, 1943, Monogr. of Echinoidea, vol. $\mathrm{III}_{3}$, p. 232, pl. XXVI, figs. 9-11; pl. XXVII, figs. $1-4,6$; pl. LXI, figs. 1-3, 8, 9, 13.

— ChANG \& Woo, 1954, p. 131, pl. I, fig. 2 ; pl. II, fig. 2 (Dairen).

Japanese Name: Kita-murasaki-uni (Murasaki-unimodoki).

Material examined: 1 specimen. Kamiiso, Hakodate Bay. T. Yusa coll. VI-1957.

2 specimens. Yoiti, rocky shore, $5 \mathrm{~m}$. K. Kawamura coll. 25-V-1960.

2 specimens. Sirikisinai, shore. M. Imajıma coll. 22-V-1960.

Description: Test strong, regularly hemispherical, flattened below. Usually 6 pore-pairs to each arc, exceptionally 5 or 7 . Spines coarse and strong, hardly exceeding ca. $25-30 \mathrm{~mm}$ in length, finely striated longitudinally, uniformly dark purple. Tube feet with bihamate spicules, often scarce or even lacking.

Measurements of five specimens (in $\mathrm{mm}$ ) are as follows.

$\begin{array}{ccccc}\text { h.d. } & \text { v.d. } & \text { Peristome (d.) } & \text { Longest spine (1.) } & \text { Locality } \\ 32 & 17 & 14 & 16 & \text { Sirikisinai } \\ 34 & 14 & 15 & 16 & " \\ 38 & 27 & 16 & 21 & \text { Kamiiso } \\ 70 & 37 & 26 & 28 & \text { Yoiti } \\ 72 & 40 & 27 & 30 & "\end{array}$

Occurrence: Common in northern Japan, from Hakodate to Sagami Bay on the Pacific coast; also from Southern Saghalin to Dairen through Korea on the the Japan Sea side, as far south as Tusima Islands. $0-180 \mathrm{~m}$ in depth.

\section{Strongylocentrotus franciscanus (A. AGASSIz)}

(P1. XL, figs. 15-16)

Toxocidaris franciscana A. AgAssiz, 1863, List of Echinoid, Bull. Mus. C. Zool., vol. 1, p. 22. (not seen)

Strongylocentrotus franciscanus A. AGASSIz, 1872-74, Rev. of Echini, p. 163, 442, pl. V.b, figs. 12 ; pl. VI, figs. 10, 10a. (not seen) 
Strongylocentrotus franciscanus YOSHIWARA, 1900, p. 382 ; pl. XII (1906), figs. 3-4 (Hakodate). - Mortensen, 1943, Monogr. of Echinoidea, vol. III $_{3}$, p. 242, pl. XVIII, figs. 1-7; pl. XXIX, fig. 14 ; pl. XXX, figs. 2-3; pl. XXXI, figs. 1-2 ; pl. XXXII, figs. 1-3 ; pl. LXI, figs. 10, 15-19, 23.

Japanese Name: Harinaga-bahun-uni (nom. nov.).

Material examined: 1 specimen. Off Kamiiso, Hakodate Bay. T. Yusa coll. VI-1957.

2 specimens. Off Muroran, $20 \mathrm{~m}$ (dredged). T. Awakura coll. 21-X-1959.

3 specimens. Saroma Lake, 10-12m. A. Obara coll. VI-1959.

The remainder in the collections of the Hokkaido Fisheries Experimental Station.

Description: Test large, strong, regularly hemispherical, more or less depressed. Oral side perfectly flat, very slightly sunken towards peristome. Usually 8-9 pore-pairs to each arc on the aboral side, exceptionally as many as 10 , or only 7. Only 2 longitudinal series of large primary tubercles, otherwise rather densely covered by smaller secondary or miliary tubercles so as to leave no bare median space in the interambulacra. Primary spines strong, rather slender, gently tapering ; those of the ambital region reach a length of ca. $43-45 \mathrm{~cm}$ in larger specimens (from Saroma Lake) and as much as the diameter of the test in a medium-sized specimen (from Hakodate Bay).

Spicules of tube feet typically bihamate, but rather scarce.

Test, when cleaned, uniformly whitish or light purplish, but covered with dark brownish skin.

Measurements of specimens here examined (in $\mathrm{mm}$ ) are as follows.

$\begin{array}{ccccc}\text { h.d. } & \text { v.d. } & \text { Peristome (d.) } & \begin{array}{c}\text { Longest } \\ \text { ambital spine (1.) }\end{array} & \text { Locality } \\ 51 & 37 & 21 & 28 & \text { Kamiiso } \\ 67 & 32 & 24 & \text { (almost missing) } & \text { Saroma Lake } \\ 70 & 38 & 24 & 43 & " \\ 71 & 34 & 27 & 45 & \text { Off Muroran } \\ 75 & 35 & 28 & 30 & \text { " }\end{array}$

Occurrence: Widely distributed in Northern Pacific, from Californian coasts to Hakodate, through Alaska and Aleutian Islands. Ca. $0-125 \mathrm{~m}$ in depth.

IRREGULARIA

Order CLYPEASTROIDA

Family Scutellidae GrAY

8. Scaphechinus mirabilis A. AgASSIZ

(P1. XL, fig. 17) 
Scaphechinus mirabilis A. AgAssiz, 1863, Proc. Acad. nat. Sci. Philad., 1863, p. 359.

Echinarachnius mirabilis A. AgASSIz, 1872, Rev. of Echini, pt. 1, p. 107 ; YoshiwARA, 1900, p. 392 ; pl. XVI (1907), figs. 9-10 ; H. L. ClarK, 1914, p. 69, pl. 125, fig. 6; MORTENSEN, 1929, p. 477 ; IKEDA, 1935, p. 202, pl. IV, figs. 5-8; IKEDA, 1940, p. 4 ; MORISHIT A, 1955, p. 231, pl. pl., VIII, figs. 3-6.

Scaphechinus mirabilis MORTENSEN, 1948, Monogr. of Echinoidea, vol. $\mathrm{IV}_{2}$, p. 375, pl. LXI, fig. 4 ; pl. LXXI, figs. 19-21.

Japanese Name: Hasunoha-kasipan.

Material examined: 9 large and small specimens. Zenibako (near Otaru), Isikari Bay, 4-8 m. K. KawAmuRA coll. 5-VI-1959.

Description: All specimens range from $28 \mathrm{~mm} \times 29 \mathrm{~mm} \times 3 \mathrm{~mm}$ to $67 \mathrm{~mm} \times 67 \mathrm{~mm}$ $\times 9 \mathrm{~mm}$ in dimension (length $\times$ width $\times$ height).

Test strong, dull purplish black, rounded pentagonal in outline, mouth central below, periproct marginal; in larger specimens the interambulacral zones on the aboral side are faintly depressed.

Occurrence: Widely distributed all along the coasts of Japan, from Isikari Bay to the south of Kyusyu.

\section{Scaphechinus brevis (IKEDA)}

(Pl. XL, fig. 18)

Echinarachnius griseus IKEDA, 1935, p. 203, pl. IV, figs. 1-4 (Muroran; Sibusi; Kitasaki) (not MORTENSEN).

Echinarachnius brevis IKEDA, 1936, p. 73, figs. 1a-1c (Muroran; Sibusi).

- IKEDA, 1940, p. 5 (Muroran).

- - Morishit A, 1955, p. 234, pl. VIII, figs. 1-2 (Onahama).

Scaphechinus tenuis (part) MoRTENSEN, 1948, Monogr. of Echinoidea, vol. $\mathrm{IV}_{2}$, p. 378, pl. LXI, figs. $3-5$; pl. LXII, fig. 4.

Japanese Name: Namiberi-hasunoha-kasipan.

Material examined: 3 dried specimens. Siraoi, near Muroran (stranded ashore). T. Yамамото coll. 7-VIII-1956.

1 specimen. Kamiiso, Hakodate Bay. T. YusA coll. VI-1957.

Description: Test roughly pentagonal in outline, wider than long, posterior margin conspicuously wavy, aboral interambulacral depressions hardly recognizable, oral side perfectly flat, evenly dark purple in color, mouth central, periproct supramarginal, actinal ambulacral furrows bifurcated rather close to mouth.

A specimen from Kamiiso measures $53 \mathrm{~mm}$ in length, $56 \mathrm{~mm}$ in width and $6 \mathrm{~mm}$ in height.

Occurrence: Known only from Japan, as cited above.

\section{Scaphechinus griseus (MORTENSEN)}

(Pl. XL, fig. 19) 
Echinarachnius griseus MORTENSEN, 1927, p. 195, pl. I, figs. 1-4, text-figs. 1-2 (Yamagata-ken, northern Japan); MORTENSEN, 1929, p. 477 (Mutu Bay); IKEDA, 1936, p. 1233, fig. 2 ; DiAKonov, 1938, p. 498 (Siaukhu Bay, Japan Sea); MoRISHITA, 1955, p. 234, pl. IX, figs. 1-2 (Akkesi Bay).

Non: Echinarachnius griseus IKEDA, 1955, p. 203, pl. I, figs. 1-4 (=Sc. brevis IKEDA).

Scaphechinus griseus MortensEN, 1943, Monogr. of Echinoidea, vol. IV 2 p. 379.

Japanese Name: Haiiro-hasunoha-kasipan (nom. nov.).

Material examined: One large and two young specimens. Sirikisinai, $12 \mathrm{~m}$. M. Imajima coll. 6-IV-1960.

Description: Test roughly round in outline, slightly wider than long, uniformly dark gray in alcohol; slightly wavy posteriorly; apical system and peristome slightly eccentric, a little nearer to the anterior margin ; periproct distinctly supramarginal; aboral side perfectly flat with thin edges. Pseudofasciole distinct as in Sc. mirabilis.

The largest one measures $43 \mathrm{~mm}$ in length, $47 \mathrm{~mm}$ in width and $6 \mathrm{~mm}$ in height. Two younger ones are all $9 \mathrm{~mm}$ long.

Occurrence: Known only from northern Japan (Tôhoku District, Hokkaido and southern Saghalin), also recorded from Siaukhu Bay, Japan Sea (DiAkonov).

\section{Order SPATANGOIDA}

\section{Family Loveniidae LAMBERT}

\section{Echinocardium cordatum (PENNANT)}

(P1. XL, fig. 20)

Echinus cordatus Pennant, 1777, Brit. Zool. 4, p. 58, pl. 34, fig. 75. (not seen)

Echinocardium cordatum A. AGASSIZ, 1872-74, Revision of the Echini, p. 109, 349, pl. XIX, figs. 10-17; pl. XX, figs. 5-7. (not seen)

- Mortensen, 1929, p. 478 (Aomori Bay); Ikeda, 1940, p. 5 (Muroran); Mortensen, 1951, Monogr. of Echinoidea, vol. $V_{2}$, p. 152, pl. XVIII, figs. 6-7; CHANG \& WoO, 1954, p. 135 , pl. I, figs. 3-5 (Dairen, N. China).

Japanese Name: Okame-bunbuku.

Material examined: Two specimens. Sirikisinai, 20 m. M. Imajıma coll. 22IX-1951.

Occurrence: Widely distributed in all oceans. Littoral to ca. $230 \mathrm{~m}$ in depth. In Hokkaido, this common spatangoid was recorded from Osyoro, together with Scaphechinus mirabilis, griseus and other regular forms (IснIKaWa \& YAMADA, 1957).

\section{Local Distribution of Echinoids in Hokkaido and Kurile Islands}

The following is a synoptic local distribution of the known echinoids around the coasts of Hokkaido and Kurile Islands, compiled from the occurrence of 11 
species of echinoids here described and the previous records of other species in the literature which I have not directly examined.

Therefore, this is by no means complete, since it is to be expected that further extensive explorations when undertaken in the area concerned may add a number of unknown species to our present meagre knowledge.

1. Tugaru Strait and southwestern coast of Hokkaido.

Phyllacanthus dubius (new record!)

Caenopedina mirabilis (after $\mathrm{C}_{\text {LARK, }}$ 1912)

Glyptocidaris crenularis (common in deep water)

Strongylocentrotus intermedius (common in littoral)

St. nudus (common in littoral)

St. franciscanus (occasional)

Hemicentrotus pulcherrimus (occasional ?)

Scaphechinus mirabilis (common in littoral)

Sc. brevis

Sc. griseus

Echinocardium cordatum

2. Isikari Bay (western coast of Hokkaido)

Strongylocentrotus intermedius (common, local name-gaze)

St. nudus (common, local name-nona)

Scaphechinus mirabilis (common, local name-murasakidara)

Sc. griseus (common, local name--haidara)

Echinocardium cordatum (occasional)

3. Akkesi Bay (southeastern coast of Hokkaido)

Strongylocentrotus intermedius (common)

Echinarachnius parma (after IKEDA 1940)

Scaphechinus griseus

4. Ohotsk Sea side (northeastern coast of Hokkaido)

St. intermedius (common)

St. echinoides (? local name-akanona)

St. franciscanus (new record!)

5. Northern Kurile Islands

St. echinoides (after CLARK 1913, IKEDA 1940)

St. sachalinicus ${ }^{1)}$ (after OHSHima 1933)

St. polyacanthus (after CLARK 1912, IKEDA 1940)

St. pulchellus (after Clark 1912)

St. drobachiensis (occasional in deep waters)

Echinarachnius parma var. obesus (after IKEDA 1940)

1) This species is also known from Sanriku coast (Pacific coast of Iwate-ken, Tôhoku District), but so far unrecorded from Hokkaido proper (KoY AMA, 1941). 


\section{REFERENCES}

*Agassiz, A. 1863. Synopsis of the echinoids collected by Dr. W. Stimpson on the North Pacific Exploration, under the command of Captains Ringgold and Rodgers. Proc. Acad. Nat. Sci. Philadelphia, 1863, pp. 352-361.

* 1872-74. Revision of the Echini. Illustr. Cat. M. C. Z., Harvard Coll., No. VII, parts 1-3.

Agassiz, A. and H. L. Clark 1907. Preliminary report on the Echini collected in 1906, from May to December, among the Aleutian Island, in Bering Sea, and along the coasts of Kamtchatka, Sakhalin, Korea, and Japan, by the U. S. Fish Commission Steamer "Albatross"..... Bull. M. C. Z., Harvard Coll., vol. LI, no. 5.

CHANG, F. Y. 1948. Echinoderms of Tsingtao. Contr. Inst. Zool. Nat. Acad. Peiping, vol. 4, no. 2, pp. 33-91, pls. I-II. (In Chinese with English résume.)

CHANG, F. Y. and $\mathrm{CHAO}_{\mathrm{O}}$, Pu. 1951. Notes on the white holothurian, red holothurian and white sea-urchins. Sinensia, N. S., vol. II, nos. 1-2, pp. 37-47. (In Chinese and English.)

CHANG, F. Y. and Woo, Pao-ling. 1954. On the echinoderms of Dairen and its vicinity. Acta Zool. Sinensica, vol. VI, no. 2, pp. 123-145, pls. I-II. (In Chinese with English résume.)

Clark, H. L. 1912-17. Hawaiian and other Pacific echini. Mem. M. C. Z., Harvard Coll., vol. XXXIV, no. 4 ; vol. XLVI, nos. 1-2.

DIAKONOV, A. M. 1923. Faune de la Russie et des pays limitrophes. Echinodermes (Echinodermata). Vol. I. Echinides (Echinoidea), Livr. 1. Mus. Zool. Acad. Sci., Russie. Petrograd. 361 pp., 2 pls. (In Russian.)

*_1938. Echinoids of Siaukhu Bay (Japan Sea). Rep. Japan Sea Hydrobiol. Exp. of the Zool. Inst. Acad. Sci. U.S.S.R. in 1934.

DöDERLEIN, L. 1906. Die polyporen Echinoiden von Japan. Zool. Anz., vol. XXX, no. 16, pp. 515521.

ICHIKAWA, S. and YAMADA, M. 1957. Catalogue of marine invertebrates in the vicinity of Osyoro Bay. Sapporo. 13 pp. (In Japanese.)

IKEDA, H. 1935. Note on the genus Echinarachnius of Japan. Bult. Sci. Fak. Terkul., Kjusu Imp. Univ., vol. VI, no. 3, pp. 202-208, pl. IV. (In Japanese with English rés.).

1936. Note on a new Echinarachnius from Japan. Bot. \& Zool., vol. IV, no. 7, pp. 12311233.

1940. The fauna of Akkesi Bay: VIII. Echinoidea. Annot. Zool. Japon., vol. XIX, no. 1, pp. 1-8, pls. I-II.

KAWAMURA, K. 1960. Some reports on the sea urchin (Strongylocentrotus intermedius) in Lake Saroma and on the foreshore in Abashiri. Hokusuisi Geppô, vol. 17, no. 8. pp. 308-318. (In Japanese.)

KOYAMA, S. 1937. Sansiku-ôbahun-uni (Strongylocentrotus drфbachiensis var. sachalinicus Döderlein). Collecting \& Breeding, vol. 3, no. 10, p. 298. (In Japanese.)

MorishitA, A. 1955. Notes on Echinarachnius in Japan. Mem. Coll. Sci., Univ. Kyoto, Ser. B, vol. XXII, no. 2, pp. 223-236, pls. VIII-XI.

Mortenson, Th. 1927. A new species of the genus Echinarachnius. Annot. Zool. Japon., vol. II, no. 3, pp. 195-201, pl. I.

1929. Report of the biological survey of Mutsu Bay. 13. Echinoidea. Sci. Rep. Tôhoku Imp. Univ., Ser. IV (Biol.), vol. IV, no. 3, pp. 473-479, pl. XIX.

1936. Phyllacanthus forcipulatus, sp. nov., a new cidarid from the Indian Ocean. Rec. Ind. Mus., vol. 38, pt. 3, pp. 307-309, pls. X-XII.

1928-51. A monograph of the Echinoidea. Vols. I-V. C. A. Reitzel, Copenhagen.

Nisiy Ama, S. 1957. Annotated list of echinoids dredged from the Pacific coast of Tiba Prefecture. Rec. Oceanogr. Wks. in Japan, vol. IX, no. 1, pp. 47-60.

1940. On the Japanese species of Echinarachnius. Jubilee Publ. Prof. Yabe's 60th Birthday, vol. II, pp. $803-862$, pls. $43-45$. Sendai. 
UCHIDA, T., YAMADA, Y. and HADA, Y. 1935. Akkesi Marine Biological Station of the Hokkaido Imper 1 al University. 28 pp., 9 pls. Sapporo. (In Japanese.)

UschaKov, P. (ed.) 1955. Atlas of Invertebrates of the Far East Seas of the U.S.S.R. 270 pp., 66 pls. Moscow. (In Russian.)

UTinomi, H. and MotodA, S. 1955. Method of course in marine biology: Observations of shallow-water animals. Seibutugaku Zikkenhô Kôza, vol. XC, no. 1, pp. 1-145. Nakayamasyoten, Tokyo. (In Japanese.)

YAMAguchI, H. and YAMADA, M. 1955. Marine investebrates of Northern Japan. 189 pp. Hokkaikyôiku Hyôron-sya, Sapporo. (In Japanese.)

YoshiwarA, S. 1898-1900. Japanese Echini (text). Zool. Mag., vol. 10 (1898), pp. 1-8, 73-76, 145-148, 247-250, 328-331, 439-443; vol. 12 (1900), pp. 379-405. (In Japanese.)

- 1904-08. Japanese Echini (plates). Zool. Mag., vol. 16 (1904), pls. I-II ; vol. 17 (1905), pls. III-VII ; vol. 18 (1906), pls. VIII-XIII ; vol. 19 (1907), pls. XIV-XIX; vol. 20 (1908), pls. $\mathrm{XX}-\mathrm{XXI}$; Explanation of all plates : vol. 18 (1906), App. (1)-(5).

(* Not directly consulted.) 


\section{EXPLANATION OF PLATES XXXVI-XL}

Plate XXXVII

Fig. 1. Phyllacanthus dubius (BRANDT, ) aboral side. Off Matuura, $20 \mathrm{~m}$. About $\times 0.65$.

Fig. 2. The same, oral side. About $\times 0.65$.

\section{Plate XXXVIII}

Fig. 3. Glyptocidaris crenularis A. AgASsiz, aboral side. Sirikisinai, $25 \mathrm{~m}$. About $\times 1$.

Fig. 4. The same, oral side. About $\times 1$.

Fig. 5. Strongylocentrotus drbbachiensis (O. F. MüLLER), aboral side. SE of Kamtchatka Peninsula, $220 \mathrm{~m}$. About $\times 0.9$.

Fig. 6. The same, aral side. About $\times 0.9$.

Fig. 7. Strongylocentrotus echinoides (A. AGASSIZ et H. L. CLARK), aboral side. Off Tokoro, $45 \mathrm{~m}$. About $\times 1.3$.

Fig. 8. The same, oral side. About $\times 1.3$.

\section{Plate XXXIX}

Fig. 9. Strongylocentrotus intermedius (A. AGASSIZ), robust-spined normal form, aboral side. Saroma Lake, $5 \mathrm{~m}$. About $\times 1$.

Fig. 10. Strongylocentrotus intermedius (A. AGASSIZ), slender-spined form, aboral side. Yoiti, $5 \mathrm{~m}$. About $\times 1$.

Fig. 11. Strongylocentrotus intermedius (A. AGASSIz), albino form, aboral side. Sirikisinai, $12 \mathrm{~m}$. About $\times 0.9$.

Fig. 12. The same, oral side. About $\times 0.9$.

(In both the photographs 11 and 12, black-colored patterns are artificial in preservation.)

Fig. 13. Strongylocentrotus nudus (A. AGAssiz), aboral side. Yoiti, $5 \mathrm{~m}$. About $\times 0.7$.

Fig. 14 The same, oral side. About $\times 0.7$.

\section{Plate XL}

Fig. 15. Strongylocentrotus franciscanus (A. AgAssiz), aboral side. Saroma Lake, $10-12 \mathrm{~m}$. About $\times 0.52$.

Fig. 16. The same, oral side. About $\times 0.46$.

Fig. 17. Scaphechinus mirabilis A. AgAssiz, oral side. Zenibako, sandy shore. About $\times 1$.

Fig. 18. Scaphechinus brevis (IKEDA), oral side. Kamiiso. About $\times 1.07$.

Fig. 19. Scaphechinus griseus (MORTENSEN), oral side. Sirikisinai, $12 \mathrm{~m}$. About $\times 1.36$.

Fig. 20. Echinocardium cordatum (PenNañT), oral side. Sirikisinai, $20 \mathrm{~m}$. About $\times 1$. 2 . 
Publ. Seto Mar. Biol. Lab., VIII, 2 (1960) PLATE XXXVII
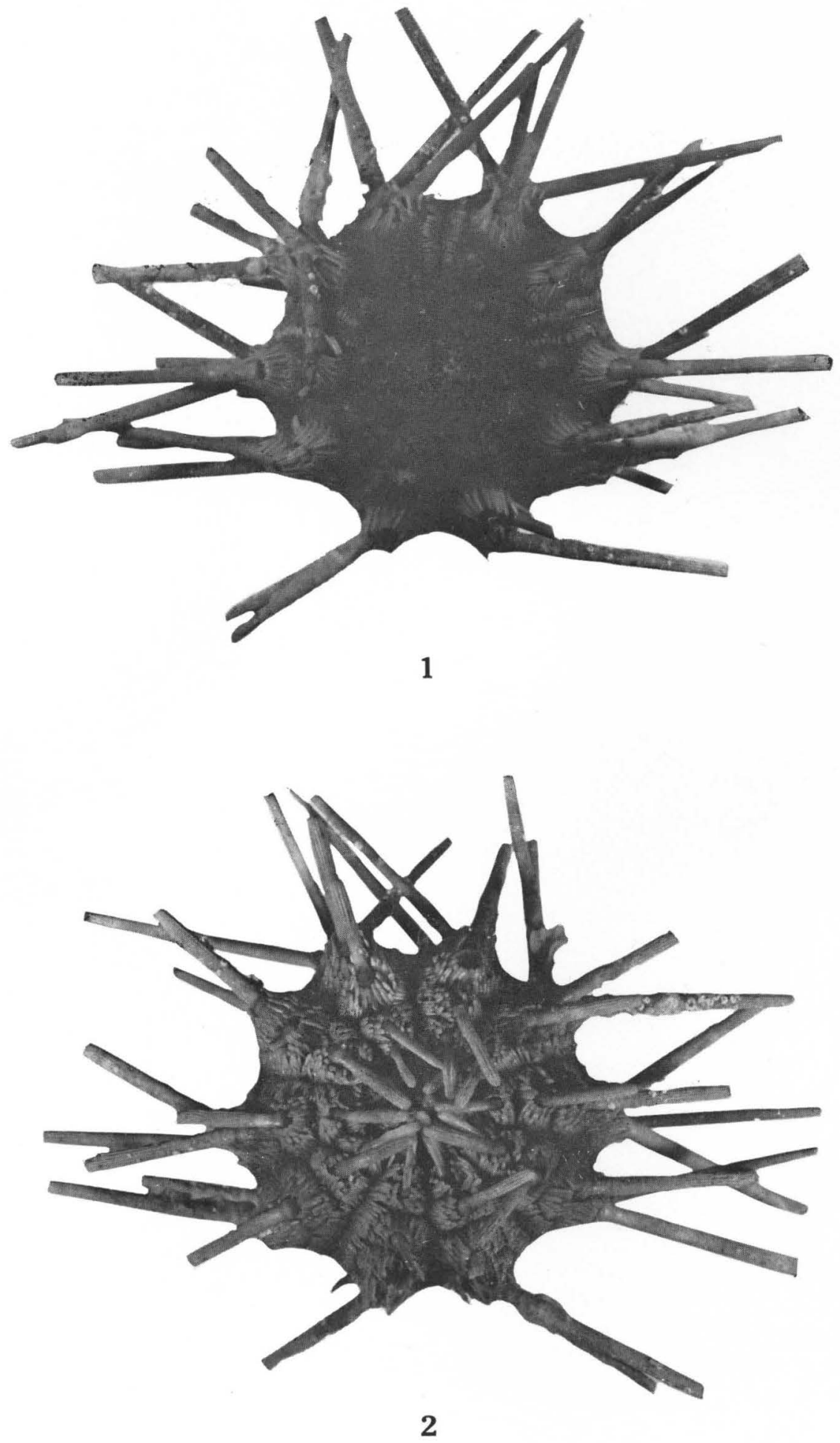

H. Utinomi: Echinoids from Hokkaido and the Neighbouring Subarctic Waters. 
Publ. Seto Mar. Biol. Lab., VIII, 2 (1960)

PLATE XXXVIII
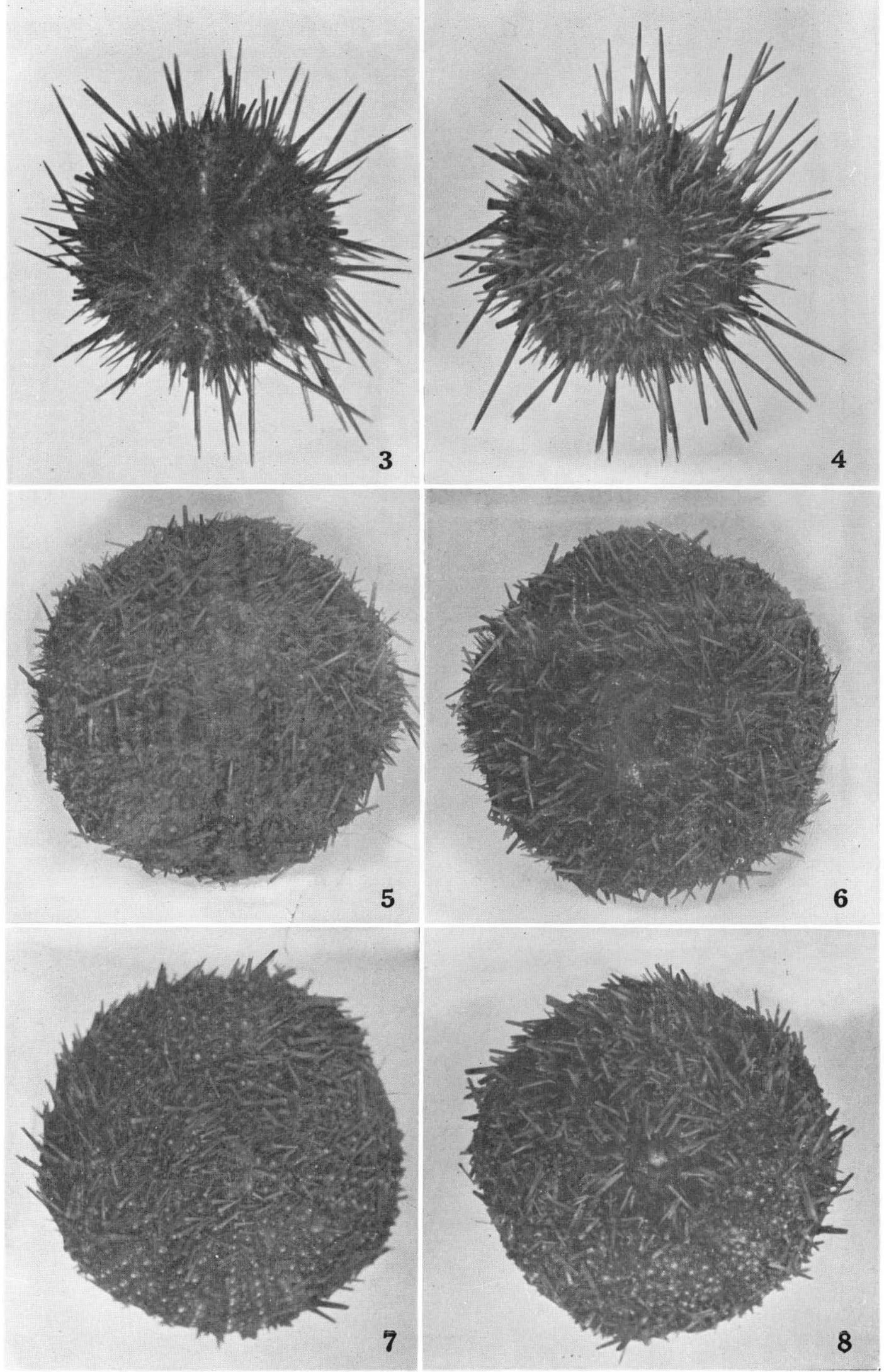

H. Utinomi: Echinoids from Hokkaido and the Neighbouring Subarctic Waters. 

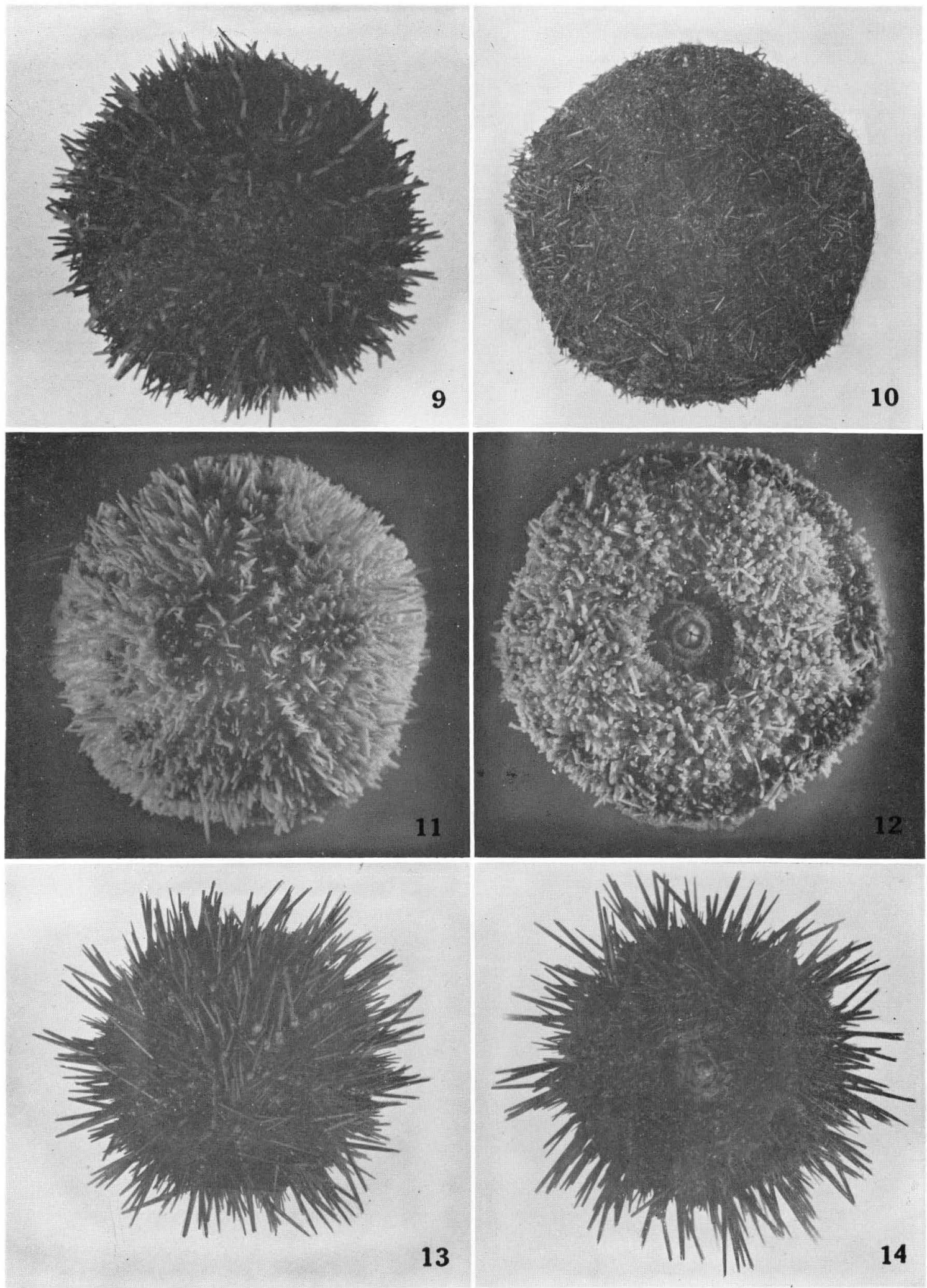

H. Utinomi : Echinoids from Hokkaido and the Neighbouring Subarctic Waters. 

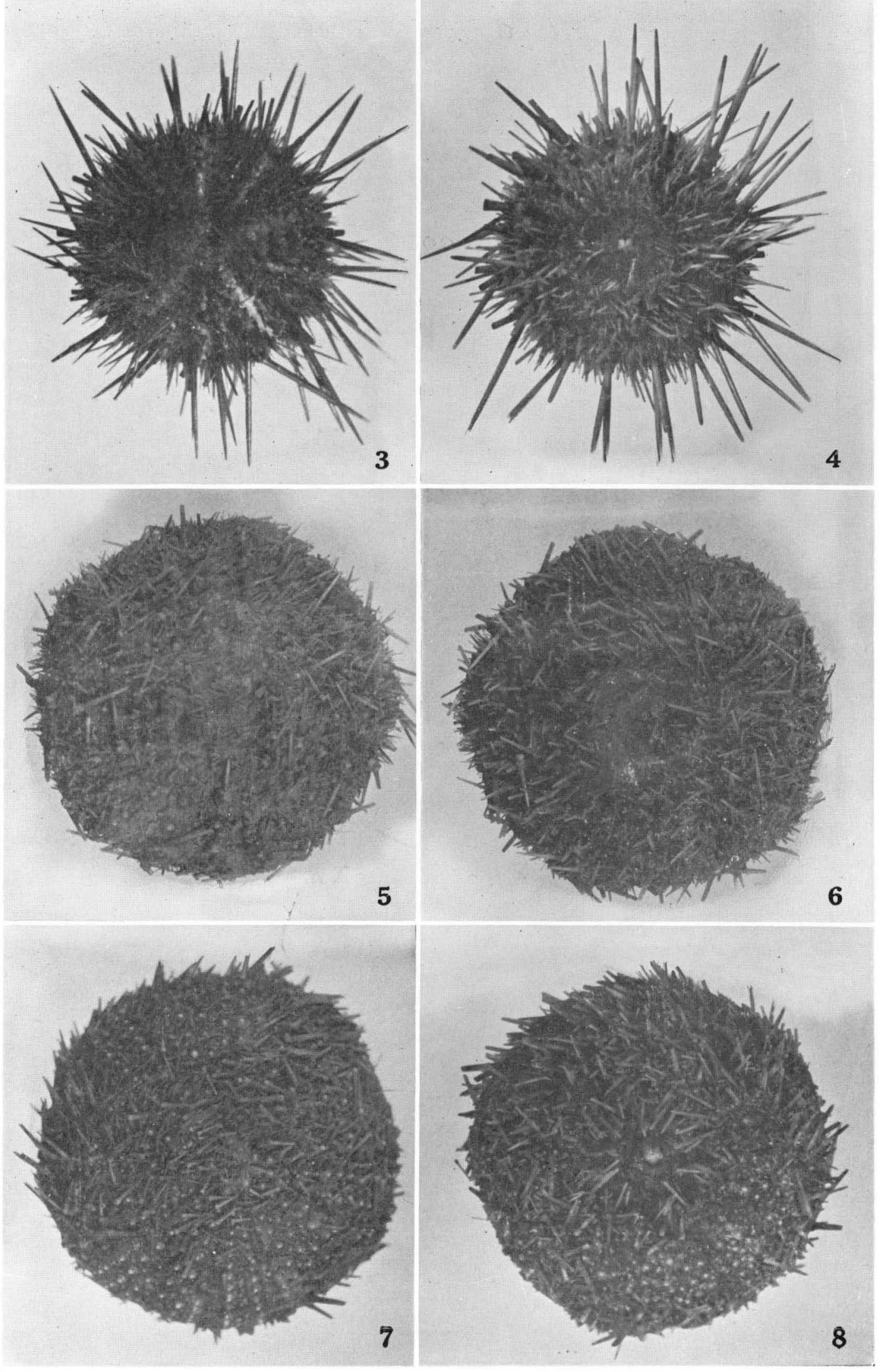

H. Utinomi: Echinoids from Hokkaido and the Neighbouring Subarctic Waters. 